\title{
History and Memory: Present Reflections on the Past to Build Our Future.
}

David Bartel

\section{(2) OpenEdition}

\section{Journals}

Édition électronique

URL : http://journals.openedition.org/chinaperspectives/4877

DOI : $10.4000 /$ chinaperspectives. 4877

ISSN : 1996-4617

Éditeur

Centre d'étude français sur la Chine contemporaine

\section{Édition imprimée}

Date de publication : 1 septembre 2009

ISSN : 2070-3449

Référence électronique

David Bartel, « History and Memory: Present Reflections on the Past to Build Our Future. », China Perspectives [En ligne], 2009/3 | 2009, mis en ligne le 16 octobre 2009, consulté le 21 septembre 2020. URL : http://journals.openedition.org/chinaperspectives/4877 ; DOI : https://doi.org/10.4000/ chinaperspectives. 4877

Ce document a été généré automatiquement le 21 septembre 2020.

(C) All rights reserved 


\title{
History and Memory: Present Reflections on the Past to Build Our Future.
}

\author{
David Bartel
}

1 This book is a compilation of proceedings from an international conference held by the Ricci Institute in 2005 in Macau, the fifth in a series dedicated to reflections on major topics such as art, law, and religion. ${ }^{1}$ One should first note both the excellent editing work and the high quality of the overall set of contributions compiled here to address the complex themes of memory and history in China and elsewhere. The distinctive characteristic of this work is a multidisciplinary approach that uses the Spanish Inquisition, the French Resistance, and the memory of the Holocaust to illuminate blind spots in Chinese memory and help define the difficulties of dealing with questions of memory. The inevitable risk of such a profusion (around 30 contributions) is to dilute the book's objective through too many viewpoints, methods, and themes. It is indeed impossible to read all of the texts with the same interest. The richness of the whole, however, leaves room for each reader to make his or her own choice. The work in fact allows the multiplicity of contemporary historiographic approaches and their relevance to be assessed, and at the same time the dramatic Chinese experience of the twentieth century to be compared with the no less tragic fate of the century's other victims.

2 In a long introduction, Du Weiming recalls both the role of the historian and the specific characteristics of this profession in China (pp. 16-17). Above all, he stresses the amnesia that marks the history of the twentieth century in China (p. 18) and the will of the government only to look towards the future in order to better transform the past into a hagiographic narrative, from which only the anti-Japanese resistance and the rise of the Chinese Communist Party (CCP) are able to emerge and are used to mask the ideological vacuity of the Party and the fragility of the political system (p. 20). For him, the "refusal to allow full investigation of what was, in reality, the "anti-cultural revolution" and to acknowledge the violent suppression of students on 4 June 1989 is a 
clear indication that the politically motivated attempt to wipe out collective memory is a "salient feature of ideological control in contemporary China" (p. 21). Du Weiming concludes his contribution in highly pessimistic fashion. For him, the chances of successfully implementing a peaceful, open, and pluralist development are very slim. Nevertheless, he says, the effort is meaningful and necessary (p. 32).

The methodological virtuosity of the contribution from Chen Fangchun is worth underlining. By taking into account three types of data referring to the same event (official documents, recollections by official personalities, oral memory of protagonists and witnesses), he offers us a reading of the Pingyuan Incident, which took place in Shandong during the Boxer Rebellion, from three different angles. This same history recounted three times is a delectable exercise in style that reveals the difficulty of establishing historical truth from multiple sources. An analysis of the limits and relevance of this triple perspective allows the reality of the facts to be outlined, if not to be fully grasped (p. 139). However, despite the profusion of sources, the Pingyuan Incident remains characterised by areas of shadow and ambiguity that prompt the author to raise the question of the possibility of historical truth. He thinks that if it is impossible to obtain all of the facts, research into this particular incident can still offer tools for a better comprehension of the Boxer Rebellion as a whole (p. 142).

4 Jin Guantao and Liu Qingfeng, for their part, propose a different methodological approach by means of an astonishing re-reading of the development of the Chinese conception of international relations in the late nineteenth century. They explain how, from the fact of the discursive development that substituted "the world under heaven" (tianxia) with the notion of "myriad countries" (wanguo), the confrontations first of all between China and France and then between China and Japan became inevitable. They rely on a quantitative statistical method supposedly emerging from Western accounts constructed in Asia (p. 266), exposing the conceptions concealed behind the events in order to re-establish the reality of historical fact (p. 253). They validate here the choice of the "linguistic turn" that they took almost a decade ago and have made the methodological heart of their last work. ${ }^{2}$ This "turn," in reality more terminological than linguistic, is a method to demonstrate that by following the development of the meaning of the concepts that define a historical event it is possible to rewrite and reinterpret the meaning of certain moments in the history of modern and contemporary China in a more objective manner. The pair thus offers us an interesting re-reading of the events of 1911 surrounding the reception and the development of the concept of "revolution" (pp. 257-59). As far as the Sino-Japanese War of 1895 is concerned, Jin and Liu maintain that the quantitative method that they use is one possible way of emerging from the "blind emotion" that renders the relations between the two neighbours opaque (p. 265).

5 The contributions from Jean-Philippe Béja, Michel Bonnin, and Xu Youyu belong to the same field of investigation - that of the difficulties of conceiving and writing the memory of the twentieth century in China - from a plural perspective once again. JeanPhilippe Béja continues to study the difficulty of structuring an opposition movement when each generation is brought up in a profusion of glorious commemorations in which the blind points of the past are systematically rewritten. A "disjointed" and amnesic memory is responsible, in his opinion, for the impossibility of transmitting normally the experience of one generation to the next. This occlusion of memory thus obliges each generation to rethink the political problems that arise without the benefit 
of lessons painfully learned by the previous generation. ${ }^{3}$ Michel Bonnin concentrates more particularly on the debate that animates the generations that lived through the movement that saw "educated youth" sent down to the countryside. He explains to us the difficulties in organising a collective memory between a monopoly of history jealously guarded by the Party and the cracks of a public space with unstable and poorly defined contours (pp. 465-8). ${ }^{4}$

6 The very personal contribution of Xu Youyu evokes the author's own experience of the atrophying of memory. Xu draws on his experience as a Red Guard to regret the absence of a collective memory that alone could be transformed into history in order to avoid such a catastrophe being repeated. While Simon Leys has already compared the longevity of the Chinese tradition with that of the Jewish tradition, Xu Youyu calls on Vera Schwarcz and Elie Wiesel to emphasise the capacity of the Jewish people to look back on even the most painful of memories in order to rethink them and bring them into some kind of system. He uses this comparison to demonstrate the capacity of some to transform a collective memory into a shared history and to denounce the incapacity of others to transform several dramatic and traumatic episodes into a collective unconscious. For Vera Schwarcz, "[t]hese true memories are the very source of the strength that has sustained the Jewish people to tolerate the miserable time" (p. 449). $\mathrm{Xu}$ can only regret the capacity to forget of the generation that lived through the Cultural Revolution and its inability to examine its shared experience (p. 454).

7 In a now classic work, Alexander and Margarete Mitscherlich analyse the process linked to the boundless adoration of a leader who offered his people a degree of pride that it could not have achieved through its own efforts and to his disappearance in a situation of defeat and chaos. ${ }^{5}$ The report that they draw up concerning Germany in the 1960s (the book was first published in 1967) is astonishingly close to the relationship between past and present in contemporary China. First, they describe a weighty tendency to keep at bay all public reflection on the past, something that $\mathrm{Xu}$ Youyu confirms when he contrasts, in China, a normal individual capacity to recall the past with a totally defective collective memory (p. 450). Then, the pair of German psychoanalysts evokes the atomisation of memories shared by groups of survivors. It is enough to read the contribution of Michel Bonnin to understand that if 17 million "young intellectuals" indeed saw their lives turned upside down by the "Down to the Countryside" Movement, the memory of the "Lost Generation" remains fragmented between silent grief, youthful nostalgia, and the oscillations of the authorities (pp. 464-65). Finally, post-war society in both Germany and France, like that of today's China, was focused on the present and oriented toward the future, divided between daily preoccupations and promises of future economic success. ${ }^{6}$

8 The parallel must end there, however, as the particular feature of the Chinese situation is that the initial victims of persecution, the "intellectuals," who would henceforth be unable to gain the necessary distance to transform their memories into history, now live side by side with their persecutors. This is one particular Chinese characteristic that explains for Suzanne Weigelin-Schwiedrzik the impossibility of escaping from memorial fragmentation to undertake the historical "master narrative" of the People's Republic. $^{8}$ The ignorance that the generations have of the most recent past is certainly a weakness of the democratic movement in China today. The young Red Guard Wei Jingsheng grew up amid the myth of the rightists of 1957 (Béja, pp. 211-12), just as Xu Youyu did (pp. 451-53). This ignorance of the most recent past permitted the violence 
exercised by the generation of Red Guards on its predecessors and is also responsible for the impossible uniting of different generations of intellectuals in Tiananmen Square in 1989. ${ }^{9}$ Rana Mitter reminds us, however, that in other contexts memory has only been successfully deployed with the aim of national reconciliation during a significant democratisation movement, for example in East Germany, in Taiwan, or in postapartheid South Africa (p. 478).

Finally, to conclude this far from exhaustive look at this collection from the Ricci Institute, the text by the curator of the Yad Vashem Holocaust History Museum is undoubtedly the most moving part of the book. The museum of the Cultural Revolution so dear to the late Ba Jin and the museography of Chinese memory remain to be built. Ms. Haviva Peled-Carméli offers the keys that will enable the Chinese to commemorate those who have suffered. While countless photos, films, and documents on the Holocaust exist, too often it is a camera guided by the ideology of the persecutor that is doing the filming (p. 339): as a consequence, the Yad Vashem Museum is entirely dedicated to the personal objects and histories of victims who re-emerge from anonymity into the light and illuminate the drama of their fellow human beings. By relying on the individual to recount the history of the masses, the perspective is inverted. The effect is striking. Anyone who has visited Yad Vashem can never forget Éva Modvál's doll or Bluma Wallach's broken glasses. It will one day require an immense effort on the part of the Chinese museographers to render coherent the obscured memories of the traumas of the Hundred Flowers Campaign, the Great Chinese Famine, and the Cultural Revolution. They will find a useful source of inspiration in the work of Ms. Peled-Carméli

10 Ultimately, the book as a whole allows a definition of different ways of approaching the question of the relationship between history and memory in China, at its margins and beyond. Each individual reader will be able to find here a number of paths for reflection, and academic references according to his or her field of interest and requirements. This book is thus an important contribution for those who are interested in the problems of memory in China, but it is also directed more generally at all amateur historians, who will find a complete inventory of the approaches, methods, and themes that contemporary historiography has to offer.

Translated by Nick Oates

\section{NOTES}

1. The themes tackled during the four previous conferences can be found on the Institute's website at http://www.riccimac.org/eng/mris/index.htm.

2. Jin Guantao, Liu Qingfeng, Guannianshi yanjiu (Study of the history of concepts), Hong Kong, Chinese University Press, 2008.

3. Jean-Philippe Béja develops this process of fragmentation in his work that appeared in 2004: À la recherche d'une ombre chinoise (Le Seuil). 
4. It should be noted here that the book by Michel Bonnin, Génération perdue (Paris, éditions de l'EHESS, 2004) has just been translated into Chinese by the Chinese University of Hong Kong Press, and that in one way or another it will find its way to the mainland to feed the debates on this still sensitive subject of the memory of the Cultural Revolution.

5. Alexander and Margarete Mitscherlich, Le deuil impossible: Les fondements $d u$ comportement collectif, Paris, Payot, 2005.

6. The French case of Vichy, recalls Olivier Wieviorka justly, is similar in terms of attitude towards the past (p. 499). It was the release in 1969 of the documentary Le chagrin et la pitié and the publication in 1973 of the book by historian Robert Paxton, $\mathrm{La}$ France de Vichy (Le Seuil), that enabled an exit from the Gaullian myth of a resistant France and, for French historiography, a return to this painful and politically sensitive period (pp. 505-06).

7. The particular feature of the notion of the "intellectual" in the PRC is that it is cast much wider than in the West and encompasses teachers as much as engineers or medical staff. For an attempt at a definition, see David Kelly, "Chinese Intellectuals in the 1989 Democracy Movement," in George Hicks (ed.), The Broken Mirror: China after Tiananmen, London, Longman , 1990, pp. 24-27.

8. Suzanne Weigelin-Schwiedrzik, "In Search for a Master Narrative," The China Quarterly, London, Cambridge University Press, No. 188, 2006, pp. 1086-87.

9. Jean-Philippe Béja, op. cit.; see also Chen Yan, L'éveil de la Chine, La Tour d'Aigues, L'Aube, 2002. 